\title{
ANALISIS FAKTOR-FAKTOR YANG MEMPENGARUHI KEANDALAN DAN KETEPATAN LAPORAN KEUANGAN SATUAN KERJA PERANGKAT DAERAH PADA PEMERINTAH KABUPATEN MINAHASA TENGGARA
}

\author{
Anando Iphan Kosegeran, Lintje Kalangi, Heince Wokas \\ (Email: anandokosegeran@yahoo.com)
}

\begin{abstract}
This research is motivated by the fact that the financial statements of local government in Fiscal Year 2008 through Fiscal Year 2012, getting Disclaimer opinion of the Audit Board of the Republic of Indonesia Representatives of the Province of North Sulawesi. Therefore, with stronger demand and transparency of public institutions, both the center and in the regions, the researchers are interested in examining the "analysis of the factors affecting the reliability and accuracy of financial statements on education in Southeast Minahasa regency government. This study aims to determine whether the factors of human resource capacity, utilization of information technology and internal control of accounting affect the reliability and accuracy of financial reports on education in Southeast Minahasa Government. This study uses a quantitative research that emphasizes the hypothesis testing. The analytical method used in this research is multiple linear regression analysis, whereas for the processing of research data using SPSS version 21. The test results partially variable by using the criteria of significance $<0.1$ indicates that, human resource capacity, utilization of information technology and internal accounting pegendalian significant effect on the reliability and accuracy of the financial statements of the local work force in Southeast Minahasa regency government. While the test together shows that the human resource capacity, utilization of information technology and accounting internal control significant effect on the reliability and accuracy of the financial statements of the local work force in Southeast Minahasa regency government.

Keywords: Capacity of Human Resources, Information Technology, Internal Control, Reliability and Accuracy of Government Financial Statements, SKPD.
\end{abstract}

\section{PENDAHULUAN}

Banyak pihak yang akan mengandalkan informasi dalam laporan keuangan yang dipublikasikan oleh pemerintah daerah sebagai dasar untuk pengambilan keputusan. Oleh karena itu, informasi tersebut harus bermanfaat bagi para pemakai. Sedangkan perkembangan sektor publik di Indonesia saat ini adalah menguatnya tuntutan akuntabilitas dan transparansi atas lembaga-lembaga publik, baik di pusat maupun daerah. Akuntabilitas diartikan sebagai bentuk kewajiban mempertanggungjawabkan keberhasilan atau kegagalan pelaksanaan misi organisasi dalam mencapai tujuan dan sasaran yang telah ditetapkan sebelumnya, melalui suatu media pertanggungjawaban yang dilaksanakan secara periodik (Stanbury, 2003 dikutip oleh Mardiasmo, 2006). Transparansi yaitu memberikan informasi keuangan yang terbuka dan jujur kepada masyarakat berdasarkan pertimbangan bahwa masyarakat memiliki hak untuk mengetahui secara terbuka dan menyeluruh atas pertanggungjawaban pemerintah dalam pengelolaan sumber daya yang dipercayakan kepadanya dan ketaatannya pada peraturan perundang-undangan. Dimensi akuntabilitas publik meliputi akuntabilitas hukum dan kejujuran, akuntabilitas manajerial, akuntabilitas program, akuntabilitas kebijakan, dan akuntabilitas finansial (keuangan). Terkait dengan tugas untuk menegakkan akuntabilitas finansial, khususnya di daerah, pemerintah daerah bertanggung jawab untuk mempublikasikan laporan keuangan kepada pemangku kepentingannya (stakeholder) (Indriasari, dan Narhatyo. 2008). 
Pelaporan keuangan pada laporan keuangan pemerintah masih banyak disajikan data yang tidak sesuai bahkan keliru. Hal ini dapat kita lihat pada Laporan Keuangan Pemerintah Daerah (LKPD) Kabupaten Minahasa Tenggara Tahun Anggaran 2008 sampai Tahun Anggaran 2012 mendapat opini dari Badan Pemeriksa Keuangan Republik Indonesia (BPKRI) perwakilan Provinsi Sulawesi Utara yaitu Disclaimer, pada Tahun Anggaran 2013 mendapat opini BPK-RI Tidak Wajar (TW) dan pada Tahun Anggaran 2014 mendapat opini Wajar Dengan Pengecualian (WDP) (BPK-RI Perwakilan Provinsi Sulawesi Utara). Laporan keuangan SKPD menurut Permendagri nomor 13 Tahun 2006 Tentang pengelolaan keuangan daerah disampaikan kepada Kepala Daerah melalui PPKD (pejabat pengelola keuangan daerah) paling lambat dua bulan setelah tahun anggaran berakhir, kenyataan dari tahun-tahun sebelumnya PPKD pada Kabupaten Minahasa Tenggara telah menyampaikan permintaan data laporan keuangan SKPD pada bulan pertama setalah tahun anggaran berakhir, akan tetapi sampai pada batas waktu pemasukan, laporan keuangan SKPD tidak semua pejabat pengguna anggaran sebagai pelaksana anggaran di SKPD menyampaikan laporan keuangan tesebut pada PPKD. Hal ini disimpulkan laporan keuangan SKPD masih belum memenuhi kriteria ketepatan waktu dalam penyajian laporan keuangan.

Berdasarkan pelaporan keuangan yang terjadi pada Laporan Keuangan Pemerintah Daerah (LKPD) Kabupaten Minahasa Tenggara disimpulkan, bahwa laporan keuangan tersebut masih belum memenuhi kriteria keandalan dan ketepatan waktu. Mengingat bahwa keandalan dan ketepatan waktu merupakan unsur informasi yang penting terkait dengan pengambilan keputusan berbagai pihak. Pertama yang mungkin mempengaruhi keandalan dan ketepatan laporan keuangan adalah kapasitas sumber daya manusia. Untuk menghasilkan informasi keuangan yang bermanfaat bagi para pemakai, maka laporan keuangan harus disusun oleh pegawai yang memiliki kompetensi di bidang pengelolaan keuangan daerah dan sistem akuntansi (Tuasikal, A. 2007). Disinilah peran aparatur sebagai sumber daya manusia yang memiliki kapasitas yang baik untuk mengelola keuangan daerah. Salah satu cara yang dapat ditempuh aparatur dalam peningkatan kapasitas SDM dapat dilakukan dengan Bimbingan Teknis atau pelatihan-pelatihan yang diselenggarakan oleh Kementrian Keuangan atau lembaga-lembaga Pemerintah lain yang berkaitan dengan pengelolaan keuangan, sehingga tujuan pengelolaan keuangan daerah yang baik dapat dicapai. Kedua yang mungkin mempengaruhi keandalan dan ketepatan waktu laporan keuangan adalah pemanfaatan teknologi informasi. Seperti kita ketahui bahwa total volume Anggaran Pendapatan dan Belanja Negara/Daerah (APBN/D) dari tahun ke tahun menunjukkan peningkatan yang luar biasa. Dari sisi akuntansi hal tersebut menunjukkan bahwa volume transaksi keuangan pemerintah juga menunjukkan kuantitas yang semakin besar dan kualitas yang semakin rumit dan kompleks. Peningkatan volume transaksi yang semakin besar dan semakin kompleks tentu harus diikuti dengan peningkatan kemampuan pengelolaan keuangan pemerintah (Sugijanto, 2002). Untuk itu Pemerintah dan Pemerintah Daerah berkewajiban untuk mengembangkan dan memanfaatkan kemajuan teknologi informasi untuk meningkatkan kemampuan mengelola keuangan daerah, dan menyalurkan Informasi Keuangan Daerah kepada pelayanan publik. Ketiga yang mungkin mempengaruhi keandalan laporan keuangan adalah pengendalian intern akuntansi. Sistem akuntansi sebagai sistem informasi merupakan subjek terjadinya kesalahan baik yang disengaja maupun yang tidak disengaja (Riasetiawan. 2007). Oleh karena itu sistem akuntansi memerlukan pengendalian intern atau dengan kata lain sistem akuntansi berkaitan erat dengan pengendalian intern organisasi (Mahmudi, 2007). Satuan Kerja Perangkat Daerah (SKPD) di Kabupaten Minahasa Tenggara yaitu sebagian besar SKPD belum memiliki atau mengikuti Standar Operasional Prosedur (SOP) sehingga jalannya proses administrasi dan program kegiatan sering terhambat serta kurang akurat karena tidak memiliki acuan. Berdasarkan fenomena yang terjadi peneliti tertarik untuk 
meneliti hal apa yang mungkin mempengaruhi keandalan dan ketepatan waktu laporan keuangan satuan kerja perangkat daerah pada Kabupeten Minahasa Tenggara.

Berdasarkan latar belakang yang telah diuraikan sebelumnya, maka dapat dirumuskan masalah sebagai berikut.

1. Apakah kapasitas sumber daya manusia berpengaruh terhadap keandalan laporan keuangan SKPD di Pemerintah Kabupaten Minahasa Tenggara?

2. Apakah pemanfaatan teknologi informasi berpengaruh terhadap keandalan laporan keuangan SKPD di Pemerintah Kabupaten Minahasa Tenggara?

3. Apakah pengendalian intern akuntansi berpengaruh terhadap keandalan laporan keuangan SKPD di Pemerintah Kabupaten Minahasa Tenggara?

4. Apakah kapasitas sumber daya manusia berpengaruh terhadap ketepatan laporan keuangan SKPD di Pemerintah Kabupaten Minahasa Tenggara?

5. Apakah pemanfaatan teknologi informasi berpengaruh terhadap ketepatan laporan keuangan SKPD di Pemerintah Kabupaten Minahasa Tenggara?

6. Apakah pengendalian intern akuntansi berpengaruh terhadap ketepatan laporan keuangan SKPD di Pemerintah Kabupaten Minahasa Tenggara?

\section{TINJAUAN PUSTAKA}

\section{Agency Theory (Teori Keagenan)}

Kewajiban pemanfaatan teknologi informasi oleh Pemerintah dan Pemerintah Daerah diatur dalam Hubungan keagenan merupakan suatu kontrak dimana satu orang atau lebih (prinsipal) memerintah orang lain (agen) untuk melakukan suatu jasa atas nama prinsipal serta memberi wewenang kepada agen untuk membuat keputusan yang terbaik bagi prinsipal (Jensen dan Meckling, 1976).

Dalam pelaporan keuangan, pemerintah yang bertindak sebagai agen mempunyai kewajiban menyajikan informasi yang bermanfaat bagi para pengguna informasi keuangan pemerintah yang bertindak sebagai. prinsipal dalam menilai akuntabilitas dan membuat keputusan baik keputusan ekonomi, sosial, maupun politik. Dalam suatu pemerintahan demokrasi, hubungan antara pemerintah dan para pengguna informasi keuangan pemerintah dapat digambarkan sebagai suatu hubungan keagenan (agency relationship). Dalam hal ini pemerintah berfungsi sebagai agen yang diberi kewenangan untuk melaksanakan kewajiban tertentu yang ditentukan oleh para pengguna informasi keuangan pemerintah sebagai prinsipal, baik secara langsung atau tidak langsung melalui wakil-wakilnya. Dalam hubungan keagenan, pemerintah sebagai agen harus melaksanakan apa yang menjadi kepentingan para pengguna informasi keuangan pemerintah sebagai prinsipalnya (Faristina, 2011).

\section{Teori Kepatuhan}

Teori kepatuhan telah diteliti pada ilmu-limu sosial khususnya di bidang psikologis dan sosiologi yang lebih menekankan pada pentingnya proses sosialisasi dalam mempengaruhi perilaku kepatuhan seorang individu. Tyler dalam Septiani, (2005), terdapat dua perspektif dasar dalam literatur sosiologi mengenai kepatuhan pada hukum, yang disebut instrumental dan normatif. Perspektif instrumental mengasumsikan individu secara utuh didorong oleh kepentingan pribadi dan tanggapan terhadap perubahan-perubahan dalam tangible, insentif, dan penalti yang berhubungan dengan perilaku. Perspektif normatif berhubungan dengan apa yang orang anggap sebagai moral dan berlawanan dengan kepentingan pribadi mereka.

\section{Teori Atribusi}

Pencetus teori atribusi adalah Fritz Heider yang menjelaskan tentang teori tentang penyebab seseorang melakukan perilaku tertentu.Apakah perilaku itu disebabkan olek faktor disposisional (faktor internal), misalnya sifat, karakter, sikap, dan lain sebagainya, atau disebabkan oleh keadaan eksternal, misalnya tekanan situasi atau keadaan tertentu yang 
memaksa seseorang melakukan perbuatan tertentu (Luthans, 2005). Teori Atribusi (Green and Mitchel. 1979) dalam Gifandi (2011), menjelaskan bahwa tindakan yang dilakukan seseorang disebabkan oleh atribut penyebab. Maka tindakan seorang pemimpin atau orang yang diberi kewenangan atau kekuasaan dipengaruhi oleh atribut penyebab. Tindakan kecurangan dapat dipengaruhi adanya sistem pengendalian internal dan monitoring oleh atasan.

\section{Laporan Keuangan Pemerintah}

Laporan keuangan meliputi segala aspek yang berkaitan dengan penyediaan dan penyampaian informasai keuangan. Laporan keuangan hanyalah salah satu medium dalam penyampaian informasi keuangan tersebut. Laporan keuangan pada dasarnya adalah asersi dari pihak manajemen pemerintah yang menyajikan informasi yang berguna dalam pengambilan keputusan dan untuk menunjukkan akuntabilitas entitas pelaporan atas sumber daya yang dipercayakan kepadanya.

Adapun laporan keuangan pokok yang harus disusun oleh pemerintah sebagaimana tercantum dalam Peraturan Pemerintah Nomor 71 Tahun 2013 tentang Standar Akuntansi Pemerintah Berbasis Akrual meliputi: (1) Laporan Realisasi Anggaran (LRA), (2) Laporan Perubahan Saldo Anggaran Lebih, (3) Neraca, (4) Laporan Operasional, (5) Laporan Arus Kas, (6) Laporan Perubahan Ekuitas, (7) Catatan atas Laporan Keuangan.

\section{Keandalan (Reliability)}

Keterandalan atau keandalan adalah kemampuan informasi untuk memberi keyakinan bahwa informasi tersebut benar atau valid. Informasi dalam laporan keuangan harus andal, yakni bebas dari pengertian yang menyesatkan dan kesalahan material, menyajikan setiap fakta secara jujur, serta dapat diverifikasi, Winidyaningrum, C. dan Rahmawati. (2010).

\section{Ketepatan}

Ketepatan atau ketepatwaktuan adalah tersedianya informasi bagi pembuat keputusan pada saat dibutuhkan sebelum informasi tersebut kehilangan kekuatan untuk mempengaruhi keputusan, Gusrita, Ririn (2013). Ketepatan atau ketepatwaktuan laporan adalah tersedianya informasi bagi pembuat keputusan pada saat dibutuhkan sebelum informasi tersebut kehilangan kekuatan untuk mempengaruhi keputusan, (PP. No. 24 Tahun 2005). Konstruk nilai informasi ketepatwaktuan diukur dengan indicator sebagai berikut. Timelines, Sistematis waktu dan Sistematis unsure.

\section{Kapasitas Sumber Daya Manusia}

Kapasitas sumber daya manusia adalah kemampuan seseorang atau individu, suatu organisasi (kelembagaan), atau suatu sistem untuk melaksanakan fungsi-fungsi atau kewenangannya untuk mencapai tujuannya secara efektif dan efisien. Kapasitas harus dilihat sebagai kemampuan untuk mencapai kinerja, untuk menghasilkan keluaran-keluaran (outputs) dan hasil-hasil (outcomes) (Mustafa, S. dan Rosidi. 2011).

Menurut Dunnetts dalam Indriasari, dan Narhatyo. (2008). anonim, skill adalah kapasitas yang dibutuhkan untuk melaksanakan suatu rangkaian tugas yang berkembang dari hasil pelatihan dan pengalaman. Menurut Blanchard dan Thacker (2004) dalam Indriasari, dan Narhatyo. (2008) anonim, skill seseorang tercermin dari seberapa baik seseorang dalam melaksanakan suatu kegiatan yang spesifik seperti mengoperasikan suatu peralatan, berkomunikasi efektif, atau mengimplementasikan suatu strategi bisnis.

\section{Pemanfaatan Teknologi Informasi}

Menurut O'Brien (2007:6) teknologi informasi adalah teknologi pendukung dari sistem informasi, yaitu sistem berbasis (TI) yang mengelola komponen-komponennya berupa hardware, software, netware, dataware, dan brainware untuk melakukan transformasi data menjadi informasi. Teknologi informasi dapat disimpulkan sebagai hardware, software, netware, dataware, brainware, dan teknologi pemrosesan informasi lainnya untuk mendukung sistem informasi. Teknologi informasi selain sebagai teknologi komputer (hardware dan 
software) untuk pemrosesan dan penyimpanan informasi, juga berfungsi sebagai teknologi komunikasi untuk penyebaran informasi. Komputer sebagai salah satu komponen dari teknologi informasi merupakan alat yang bisa melipatgandakan kemampuan yang dimiliki manusia dan komputer juga bisa mengerjakan sesuatu yang manusia mungkin tidak mampu melakukannya.

Tingginya biaya tenaga kerja manusia yang diperlukan dalam pemrosesan data membuat pemrosesan secara manual kurang efektif jika ditinjau dari sisi volume dan biaya pemrosesan. Pemrosesan secara manual memiliki biaya yang stabil pada angka yang cukup tinggi. Sementara dengan menggunakan mesin, meski investasi awal lebih besar biayanya, namun pada perkembangannya akan dapat mengurangi biaya pemrosesan dengan tetap menjaga volume.

\section{Pengendalian Intern Akuntansi}

Pengendalian intern meliputi struktur organisasi, metoda, dan ukuran-ukuran yang dikoordinasikan untuk menjaga kekayaan organisasi, mengecek ketelitian dan keterandalan data akuntansi, mendorong efisiensi, dan dipatuhinya kebijakan pimpinan. Menurut tujuannya, pengendalian intern dapat dibagi menjadi dua yaitu pengendalian intern akuntansi (internal accounting control) dan pengendalian intern administratif (internal administrative control). Pengawasan Intern merupakan seluruh proses kegiatan audit, reviu, evaluasi, pemantauan, dan kegiatan pengawasan lain terhadap penyelenggaraan tugas dan fungsi organisasi dalam rangka memberikan keyakinan yang memadai bahwa kegiatan telah dilaksanakan sesuai dengan tolok ukur yang telah ditetapkan secara efektif dan efisien untuk kepentingan pimpinan dalam mewujudkan tata kepemerintahan yang baik.

Untuk mencapai pengelolaan keuangan negara yang efektif, efisien, transparan, dan akuntabel, menteri/pimpinan lembaga, gubernur, dan bupati/walikota wajib melakukan pengendalian atas penyelenggaraan kegiatan pemerintahan. Pengendalian atas penyelenggaraan kegiatan pemerintahan tersebut dilaksanakan dengan berpedoman pada SPIP sebagaimana diatur dalam Peraturan Pemerintah ini. Peraturan pemerintah (PP) nomor 60 tahun 2008 SPIP bertujuan untuk memberikan keyakinan yang memadai bagi tercapainya efektivitas dan efisiensi pencapaian tujuan penyelenggaraan pemerintahan negara, keandalan pelaporan keuangan, pengamanan aset negara, dan ketaatan terhadap peraturan perundangundangan. Unsur-unsur pembentuk SPIP (sistem pengendalian intern pemerintah) antara lain: Lingkungan pengendalian, Penilaian risiko, Kegiatan pengendalian, Informasi dan komunikasi, dan Pemantauan pengendalian intern.

\section{Penelitian Terdahulu}

Gusrita, Ririn (2013) "Pengaruh pemanfaatan teknologi informasi dan sumber daya manusia terhadap keterandalan dan ketepatwaktuan pelaporan keuangan pemerintah daerah". Studi empiris pada pemerintah daerah kabupaten Inhil. Ekasari, Winda (2013) "Faktor-faktor yang mempengaruhi keandalan pelaporan keuangan pemerintah daerah kabupaten Kampar". Survei pada satuan kerja perangkat daerah kabupaten Kampar. Adriani, Wiwik (2010) "Pengaruh Kapasitas Sumber Daya Manusia dan Pemanfaatan Teknologi Informasi Terhadap Keterandalan dan Ketepatwaktuan Laporan Keuangan Pemerintah Daerah”. Studi pada Pemerintah Daerah Kabupaten Pesisir Selatan. Winidyaningrum, dan Rahmawati (2010) "Pengaruh Sumber Daya Manusia dan Pemanfaatan Teknologi Informasi Terhadap Keterandalan dan Ketepatwaktuan Laporan Keuangan Pemerintah Daerah dengan Variabel Intervening Pengendalian Intern Akuntansi". Studi empiris pada pemerintah daerah Subosukawonosraten. Wansyah, dkk. (2012) "Pengaruh kapasitas sumber daya manusia, pemanfaatan teknologi informasi dan kegiatan pengendalian terhadap nilai informasi pelaporan keuangan SKPD pada Provinsi Aceh. Indriasari, dan Narhatyo (2008) "Pengaruh kapasitas sumber daya manusia, pemanfaatan teknologi informasi dan pengendalian intern 
akuntansi terhadap nilai informasi pelaporan keuangan pemerintah daerah". Studi pada pemerintah Kota Palembang dan Kabupaten Ogah Ilir.

\section{KERANGKA KONSEPTUAL}

Kerangka konspetual bertujuan agar penelitian ini dapat terarah secara sistematis dalam suatu alur metode penelitian yang baik, sesuai dengan rumusan masalah dan tujuan penelitian yang akan dicapai. Kerangka konsep penelitian secara komprehensif perlu dibangun dengan mendasarkan kepada fakta masalah yang ada, keterkaitan variabel secara teoritis, kajian penelitian-penelitian sebelumnya, metodologi, metode analisis dan dengan keselarasan tujuan penelitian yang ingin dicapai.

Gambar 3.1 Kerangka Konseptual Penelitian

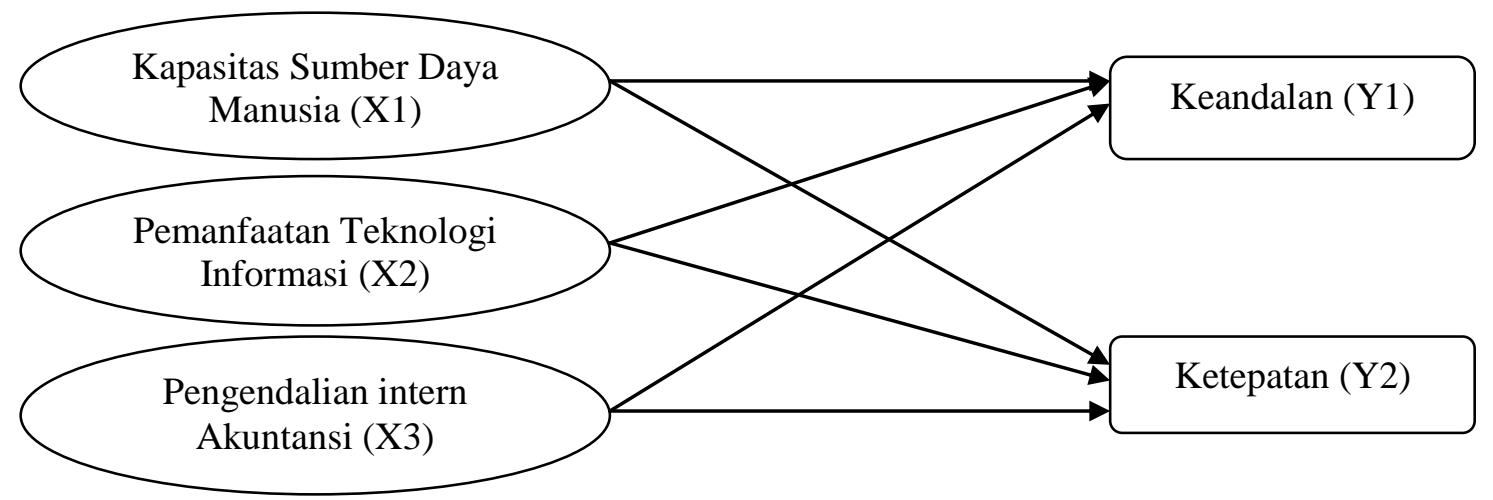

\section{Pengembangan Hipotesis}

\section{Pengaruh Kapasitas Sumber Daya Manusia Terhadap Keandalan dan Ketepatan Laporan Keuangan SKPD}

Perubahan tersebut membutuhkan dukungan teknologi dan sumber daya manusia yang memiliki latar belakang pendidikan akuntansi yang memadai. Penelitian mengenai kesiapan sumber daya manusia subbagian akuntansi pemerintah daerah dalam kaitannya dengan pertanggungjawaban keuangan daerah pernah dilakukan oleh Alimbudiono dan Fidelis (2004), Dinata (2004), Imelda (2005) serta Adriani, Wiwik (2010). Dari uraian tersebut penulis menduga terdapat hubungan positif antara kapasitas sumber daya manusia dengan keandalan laporan keuangan pemerintah daerah, maka dirumuskan hipotesis sebagai berikut:

H1 Kapasitas sumber daya manusia berpengaruh terhadap keandalan laporan keuangan Satuan Kerja Perangkat Daerah di Pemerintah Kabupaten Minahasa Tenggara.

Rendahnya pemahaman pegawai terhadap tugas dan fungsinya serta hambatan di dalam pengolahan data juga dapat berdampak pada keterlambatan penyelesaian tugas yang harus diselesaikan, salah satunya adalah penyajian laporan keuangan. Keterlambatan penyajian laporan keuangan berarti bahwa laporan keuangan belum/tidak memenuhi nilai informasi yang disyaratkan, yaitu ketepatwaktuan (Indriasari, dan Narhatyo. 2008). Dari uraian tersebut penulis menduga terdapat hubungan positif antara kapasitas sumber daya manusia dengan ketepatan laporan keuangan pemerintah daerah, maka dirumuskan hipotesis sebagai berikut:

H4 Kapasitas sumber daya manusia berpengaruh terhadap ketepatan laporan keuangan

Satuan Kerja Perangkat Daerah di Pemerintah Kabupaten Minahasa Tenggara.

Pengaruh Pemanfaatan Teknologi Informasi Terhadap Keandalan dan Ketepatan Laporan Keuangan SKPD

Perkembangan teknologi informasi tidak hanya dimanfaatkan pada organisasi bisnis tetapi juga pada organisasi sektor publik, termasuk pemerintahan. Pemerintah perlu mengoptimalisasi pemanfaatan kemajuan teknologi informasi untuk membangun jaringan 
sistem informasi manajemen dan proses kerja yang memungkinkan pemerintahan bekerja secara terpadu dengan menyederhanakan akses antar unit kerja. Pemanfaatan teknologi informasi tersebut mencakup adanya (a) pengolahan data, pengolahan informasi, sistem manajemen dan proses kerja secara elektronik dan (b) pemanfaatan kemajuan teknologi informasi agar pelayanan publik dapat diakses secara mudah dan murah oleh masyarakat di seluruh wilayah negeri ini (Hamzah, 2009 dalam Widyaningrum, 2010). Dari uraian tersebut penulis menduga terdapat hubungan positif antara pemanfaatan teknologi informasi dengan keandalan laporan keuangan pemerintah daerah, maka dirumuskan hipotesis sebagai berikut:

H2 Pemanfaatan teknologi informasi berpengaruh terhadap keandalan laporan keuangan Satuan Kerja Perangkat Daerah di Pemerintah Kabupaten Minahasa Tenggara.

Penelitian Cohen et al. (2007) dalam Winidyaningrum, dan Rahmawati. 2010. menemukan bahwa sistem/teknologi informasi yang dimiliki pemerintah daerah di kotamadya-kotamadya Yunani merupakan alat yang sangat berguna untuk menilai fungsionalitas sebuah sistem dan tingkat kesesuaian dengan lingkungan organisasional. Suatu entitas akuntansi dalam pemerintah daerah pasti akan memiliki transaksi yang kompleks dan besar volumenya. Pemanfaatan teknologi informasi akan sangat membantu mempercepat proses pengolahan data transaksi dan penyajian laporan keuangan pemerintah sehingga laporan keuangan tersebut tidak kehilangan nilai informasi yaitu ketepatan waktu. Dari uraian tersebut penulis menduga terdapat hubungan positif antara pemanfaatan teknologi informasi dengan ketepatan laporan keuangan pemerintah daerah, maka dirumuskan hipotesis sebagai berikut:

H5 Pemanfaatan teknologi informasi berpengaruh terhadap ketepatan laporan keuangan Satuan Kerja Perangkat Daerah di Pemerintah Kabupaten Minahasa Tenggara.

\section{Pengaruh Pengendalian Intern Akuntansi Terhadap Keandalan dan Ketepatan} Laporan Keuangan SKPD

Aktivitas pengendalian yang berhubungan dengan pelaporan keuangan adalah (1) identifikasi; (2) pencatatan; (3) pengukuran; (4) pengklasifikasian; (5) pengikhtisaran transaksi dan kejadian keuangan; (6) penyajian laporan; dan (7) pengiterprestasian atas hasilnya.

Dikaitkan dengan penjelasan mengenai pengendalian intern akuntansi, maka penyebab ketidakandalan laporan keuangan tersebut merupakan masalah yang berhubungan dengan pengendalian intern akuntansi. Mustafa S, dan Rosidi (2011). Dari uraian tersebut penulis menduga terdapat hubungan positif antara pengendalian intern akuntansi dengan keandalan laporan keuangan pemerintah daerah, maka dirumuskan hipotesis sebagai berikut:

H3 Pengendalian intern akuntansi berpengaruh terhadap keandalan laporan keuangan Satuan Kerja Perangkat Daerah di Pemerintah Kabupaten Minahasa Tenggara.

Salamun (2007) dalam Prapto, S. (2010). ketepatwaktuan dapat dipengaruhi berbagai macam aspek, salah satunya kemampuan sistem akuntansi. Sistem akuntansi yang baik memiliki pengendalian intern yang baik pula. Pengendalian intern ini diharapkan mampu mencegah terjadinya kesalahan dalam proses akuntansi serta dapat memberikan perlindungan bagi data organisasi dari ancaman sabotase sistem. Pengendalian intern disusun agar pelaporan keuangan dapat memenuhi asas ketertiban. Perwujudan dari asas ketertiban tersebut adalah penyampaian pelaporan keuangan secara tepat waktu. Dari uraian tersebut penulis menduga terdapat hubungan positif antara pengendalian intern akuntansi dengan ketepatan laporan keuangan pemerintah daerah, maka dirumuskan hipotesis sebagai berikut:

H6 Pengendalian intern akuntansi berpengaruh terhadap ketepatan laporan keuangan Satuan Kerja Perangkat Daerah di Pemerintah Kabupaten Minahasa Tenggara. 


\section{METODE PENELITIAN}

\section{Jenis dan Sumber Data}

Jenis data yang digunakan yaitu data kuantitatif. Sumber data yang digunakan dalam penelitian ini adalah data primer dan data sekunder, data primer adalah sumber data yang diperoleh langsung dari sumber asli. Sedangkan sumber data dalam penelitian ini berasal dari responden yaitu dari semua yang menjalankan fungsi keuangan di Satuan Kerja Perangkat Daerah Kabupaten Minahasa Tenggara. Data sekunder adalah data yang telah dikumpulkan oleh lembaga pengumpul data dan dipublikasikan kepada masyarakat pengguna data (Kuncoro, 2003:17).

\section{Populasi dan Sampel}

Populasi adalah wilayah generalisasi yang terdiri atas objek atau subjek yang mempunyai kuantitas dan karakteristik tertentu yang ditetapkan oleh peneliti untuk dipelajari dan kemudian ditarik kesimpulannya. Populasi dalam penelitian ini berjumlah 140. Populasi penelitian ini adalah Satuan Kerja Perangkat Daerah (SKPD) di Kabupaten Minahasa Tenggara. Sedangkan sampel dalam penelitian ini diambil dengan menggunakan metode sampling purposive (purposive sampling). (Kuncoro, 2003:111) bahwa secara umum jumlah sampel untuk studi korelasional, dibutuhkan minimal 30 (tiga puluh) sampel untuk menguji ada tidaknya hubungan. (Sugiyono, 2006) sampling purposive yaitu teknik penentuan sampel dengan pertimbangan tertentu, atau secara umum pengambilan sampel dilakukan sesuai dengan tujuan penelitian yang telah ditetapkan adalah pegawai di Kabupaten Minahasa Tenggara. Jumlah sampel keseluruhan yang akan di jadikan responden adalah 87 orang pegawai.

\section{Definisi Operasional dan Pengukuran Variabel}

Penelitian ini menggunakan tiga variabel independen (kapasitas sumber daya manusia, pemanfaatan teknologi informasi dan pengendalian intern akuntansi) dan dua variabel dependen (keandalan dan ketepaten). Pengukuran variabel menurut Sunyoto (2011), Dalam butir pertanyaan terdapat beberapa alternatif jawaban yang tersedia dengan skala ordinal (skala likert) yaitu menggunakan lima (5) tingkat skala sesuai alternatif jawaban. Pengukuran variabel dengan kuisioner menggunakan skala Likert lima poin, poin 5 sangat tinggi, poin 4 tinggi, poin 3 sedang, poin 2 rendah dan poin 1 sangata rendah.

\section{Lokasi dan Waktu Penelitian}

Lokasi penelitian ini dilakukan di wilayah Kabupaten Minahasa Tenggara, khususnya satuan kerja perangkat daerah (SKPD) yang ada di Lingkungan Pemerintah Kabupaten Mnahasa Tenggara. Waktu pelaksanaan dalam penelitian ini dilakukan selama 6 bulan yaitu pada bulan April sampai dengan September Tahun 2015.

\section{ANALISIS DAN PEMBAHASAN HASIL Analisis Regresi Linear Berganda:}

\begin{tabular}{|c|c|c|c|c|c|c|}
\hline \multirow{3}{*}{\multicolumn{2}{|c|}{ Model }} & \multicolumn{5}{|c|}{ Coefficients $^{\mathrm{a}}$} \\
\hline & & \multicolumn{2}{|c|}{$\begin{array}{c}\text { Unstandardized } \\
\text { Coefficients }\end{array}$} & $\begin{array}{l}\text { Standardized } \\
\text { Coefficients }\end{array}$ & \multirow[t]{2}{*}{$\mathrm{t}$} & \multirow[t]{2}{*}{ Sig. } \\
\hline & & $\mathrm{B}$ & Std. Error & Beta & & \\
\hline & (Constant) & 11.174 & 3.166 & & 3.529 & .001 \\
\hline & Kapasitas Sumber Daya Manusia & .113 & .063 & 191 & 1.792 & .077 \\
\hline & Pemanfaatan Teknologi Informasi & -.103 & .051 & -.210 & -2.023 & .046 \\
\hline & Pengendalian Intern Akuntansi & .454 & .097 & .521 & 4.656 & .000 \\
\hline
\end{tabular}

Dari model regresi di atas dapat dijelaskan sebagai berikut. Konstanta $\alpha$ sebesar 11,174 artinya jika variabel kapasitas sumber daya manusia (X1), pemanfaatan teknologi informasi (X2), dan pengendalian intern akuntansi (X3) nilai adalah 0 , maka besarnya keandalan laporan keuangan SKPD di Lingkungan Pemerintah Kabupaten Minahasa 
Tenggara adalah sebesar 11,174. Nilai $\beta_{1}$ yang merupakan koefisien regresi dari variabel kapasitas sumber daya manusia (X1) sebesar 0,113 , nilai $\beta_{2}$ yang merupakan koefisien regresi dari variabel pemanfaatan teknologi informasi (X2) sebesar $-0,103$, nilai $\beta_{3}$ yang merupakan koefisien regresi dari variabel pengendalian intern akuntansi (X3) sebesar 0,454.

Coefficients $^{\mathbf{a}}$

\begin{tabular}{|c|c|c|c|c|c|}
\hline \multirow[t]{2}{*}{ Model } & \multicolumn{2}{|c|}{$\begin{array}{l}\text { Unstandardized } \\
\text { Coefficients }\end{array}$} & $\begin{array}{l}\text { Standardized } \\
\text { Coefficients }\end{array}$ & \multirow[t]{2}{*}{$\mathrm{t}$} & \multirow[t]{2}{*}{ Sig. } \\
\hline & $\mathrm{B}$ & Std. Error & Beta & & \\
\hline (Constant) & 3.952 & 1.636 & & 2.415 & .018 \\
\hline Kapasitas Sumber Daya Manusia & .079 & .033 & .261 & 2.434 & .017 \\
\hline Pemanfaatan Teknologi Informasi & .054 & .026 & .215 & 2.054 & .043 \\
\hline Pengendalian Intern Akuntansi & .102 & .050 & .228 & 2.029 & .046 \\
\hline
\end{tabular}

a. Dependent Variable: Ketepatan

$$
\begin{gathered}
Y_{2}=\alpha+\beta_{1} X_{1}+\beta_{2} X_{2}+\beta_{3} X_{3} \\
Y_{2}=3,952+0,079 X_{1}+0,054 X_{2}+0,102 X_{3}
\end{gathered}
$$

Dari model regresi hipotesis kedua di atas dapat dijelaskan sebagai berikut. Konstanta $\alpha$ sebesar 3,952 artinya jika variabel kapasitas sumber daya manusia(X1), pemanfaatan teknologi informasi (X2), dan pengendalian intern akuntansi (X3) nilai adalah 0, maka besarnya ketepatan laporan keuangan SKPD di Lingkungan Pemerintah Kabupaten Minahasa Tenggara adalah sebesar 3,952. Nilai $\beta_{1}$ yang merupakan koefisien regresi dari variabel kapasitas sumber daya manusia (X1) sebesar 0,079 , nilai $\beta_{2}$ yang merupakan koefisien regresi dari variabel pemanfaatan teknologi informasi (X2) sebesar 0,054 , nilai $\beta_{3}$ yang merupakan koefisien regresi dari variabel pengendalian intern akuntansi (X3) sebesar 0,102.

\section{Pembahasan}

Dengan menggunakan variabel dependen keandalan pengujian koefisien korelasi linier yang dihasilkan antara variabel kapasitas sumber daya manusia (X1), pemanfaatan teknologi informasi (X2), pengendalian intern akuntansi (X3) dan variabel keandalan (Y1) adalah sebesar 0,567. Nilai korelasi (R) sebesar 0.567 menunjukkan bahwa adanya hubungan yang kuat antara variabel X1, X2, dan X3 dengan variabel Y1. Sedangkan nilai R Square atau koefisien determinasi $\left(\mathrm{R}^{2}\right)$ sebesar 0.321 menunjukkan bahwa kontribusi variabel $\mathrm{X} 1, \mathrm{X} 2$, dan X3 untuk menjelaskan model variabel Y1 adalah sebesar 32,1\% dan sisanya 67,9 \% dijelaskan oleh faktor lain yang tidak dimasukkan dalam penelitian ini. Sedangkan dengan menggunakan variabel dependen ketepatan pengujian koefisien korelasi linier yang dihasilkan antara variabel kapasitas sumber daya manusia (X1), pemanfaatan teknologi informasi (X2), pengendalian intern akuntansi (X3) dan variabel ketepatan (Y2) adalah sebesar 0,561. Nilai korelasi (R) sebesar 0.561 menunjukkan bahwa adanya hubungan yang kuat antara variabel X1, X2, dan X3 dengan variabel Y2. Sedangkan nilai R Square atau koefisien determinasi $\left(\mathrm{R}^{2)}\right.$ sebesar 0.315 menunjukkan bahwa kontribusi variabel $\mathrm{X} 1, \mathrm{X} 2$, dan X3 untuk menjelaskan model variabel Y2 adalah sebesar $31,5 \%$ dan sisanya $68,5 \%$ dijelaskan oleh faktor lain yang tidak dimasukkan dalam penelitian ini.

Pengujian hipotesis menggunakan taraf signifikasi sebesar $10 \%$ untuk mengetahui pengaruh setiap variabel bebas/independen $(\mathrm{X})$ terhadap variabel terikat/dipendenden $(\mathrm{Y})$ secara parsial dengan menggunakan uji t memakai kriteria yaitu apabila signifikan $<0,1$ maka $\mathrm{H}_{0}$ ditolak, $\mathrm{H}_{\mathrm{a}}$ diterima dan apabila signifikan $>0,1$ maka $\mathrm{H}_{0}$ diterima, $\mathrm{H}_{\mathrm{a}}$ ditolak.

\section{Kapasitas Sumber Daya Manusia (X1) terhadap Keandalan (Y1)}

Tingkat signifikasi dari variabel kapasitas sumber daya manusia (X1) adalah 0,077< 0,1 hal ini berarti bahwa kapasitas sumber daya manusia berpengaruh secara signifikan terhadap keandalan laporan keuangan SKPD pada Pemerintah Kabupaten Minahasa Tenggara yaitu 0,077 atau lebih kecil dari 0,1 . Hasil penelitian ini mendukung hipotesis pertama yang telah dirumuskan yaitu kapasitas sumber daya manusia berpengaruh terhadap keandalan 
laporan keuangan satuan kerja perangkat daerah di Pemerintah Kabupaten Minahasa Tenggara. Penelitian ini sejalan dengan penelitian Adriani, Wiwik (2010) yaitu kapasitas sumber daya manusia mempunyai pengaruh yang signifikan terhadap keandalan laporan keuangan. Kondisi kapasitas sumber daya manusia yang ada ditata usaha keuangan yang belum mendukung dari segi jumlah dan latarbelakang pendidikan, akan tetapi mereka mampu mangatasinya dengan bimtek dan pelatihan yang diadakan oleh Pemerintah Kabupaten atau dengan yang bekerjasama dengan instansi lain diluar wilayah Pemerintah Kabupaten Minahasa Tenggara mengenai pengelolaan keuangan.

\section{Pemanfaatan Teknologi Informasi (X2) terhadap Keandalan (Y1)}

Tingkat signifikasi dari variabel pemanfaatan teknologi informasi (X2) adalah 0,046 $<0,1$, hasil penelitian ini mendukung hipotesis kedua yang telah dirumuskan yaitu pemanfaatan teknologi informasi berpengaruh terhadap keandalan laporan keuangan satuan kerja perangkat daerah di Pemerintah Kabupaten Minahasa Tenggara. Penelitian ini sejalan dengan penelitian Indriasari, D. dan E. Narhatyo (2008) pemanfaatan teknologi informasi yang meliputi teknologi komputer dan teknologi komunikasi dalam pengelolaan keuangan daerah akan meningkatkan pemrosesan transaksi dan data lainnya, keakurasian dalam perhitungan, serta penyiapan laporan dan output lainnya lebih tepat waktu.

\section{Pengendalian Intern Akuntansi (X3) terhadap Keandalan (Y1)}

Tingkat signifikasi dari variabel pengendalian intern akuntansi (X3) adalah $0,000<0$, hasil penelitian ini mendukung hipotesis ketiga yang telah dirumuskan yaitu pengendalian intern akuntansi berpengaruh terhadap keandalan laporan keuangan satuan kerja perangkat daerah di Pemerintah Kabupaten Minahasa Tenggara. Penelitian ini sejalan dengan penelitian Mustafa S, dan Rosidi. (2011) dengan adanya pengendalian yang dilakukan Pemerintah Kabupeten Minahasa Tenggara seperti salah satunya rekonsiliasi laporan keuangan SKPD dapat mendeteksi kesalahan-kesalahan yang dilakukan sehingga dalam laporan keuangan pemerintah daerah sudah dapat di perbaiki.

\section{Kapasitas Sumber Daya Manusia (X1) terhadap Ketepatan (Y2)}

Tingkat signifikasi dari variabel kapasitas sumber daya manusia (X1) adalah 0,017 < 0,1 , hasil penelitian ini mendukung hipotesis keempat yang telah dirumuskan yaitu kapasitas sumber daya manusia berpengaruh terhadap ketepatan laporan keuangan satuan kerja perangkat daerah di Pemerintah Kabupaten Minahasa Tenggara. Penelitian ini sejalan dengan penelitian Indriasari, dan Narhatyo. (2008) jika seorang pegawai diberi tugas sesuai dengan latarbelakang pendidikan maka dia akan menyelesaikan tugas dengan baik dan tepat waktu, sebaliknya jika diberi tugas atau pekerjaan bukan pada pada latarbelakang pendidikannya maka pegawai tersebut akan mengalami kesulitan dalam melaksanakan tugas atau pekerjaannya sehingga pada akhirnya tidak sesuai yang diharapkan dengan target yang diberikan oleh atasan. Dalam penelitian ini banyak pegawai di SKPD pada Pemerintah Kabupaten Minahasa Tenggra diberikan tugas tidak sesuai dengan bidang keilmuannya sehingga dalam prosesnya pegawai tersebut mengalami kesulitan untuk menghasilkan output tepat pada waktunya.

\section{Pemanfaatan Teknologi Informasi (X2) terhadap Ketepatan (Y2)}

Tingkat signifikasi dari variabel pemanfaatan teknologi informasi (X2) adalah 0,043 < 0 , hasil penelitian ini mendukung hipotesis kelima yang telah dirumuskan yaitu pemanfaatan teknologi informasi berpengaruh terhadap ketepatan laporan keuangan satuan kerja perangkat daerah di Pemerintah Kabupaten Minahasa Tenggara. Penelitian ini sejalan dengan penelitian Winidyaningrum, dan Rahmawati. (2010) pemanfaatan teknologi informasi akan sangat membantu mempercepat proses pengolahan data transaksi dan penyajian laporan keuangan pemerintah dengan tepat waktu. Pada penelitian ini SKPD pada Pemerintah Kabupaten Minahasa Tenggara sudah memanfaatkan teknologi informasi dalam proses transaksi dan pengolahan data laporan keuangan di karenakan prosesnya lebih cepat dalam suatu kegiatan 
pada SKPD seperti pembuatan Surat Perintah Pembayar (SPP), Surat Perintah Membayar (SPM) dan Surat Perintah Pencairan Dana (SP2D) dalam transaksi keuangan.

\section{Pengendalian Intern Akuntansi (X3) terhadap Ketepatan (Y2)}

Tingkat signifikasi dari variabel pengendalian intern akuntansi (X3) adalah 0,046 < 0,1 , hasil penelitian ini mendukung hipotesis keenam yang telah dirumuskan yaitu pengendalian Intern akuntansi berpengaruh terhadap ketepatan laporan keuangan satuan kerja perangkat daerah di Pemerintah Kabupaten Minahasa Tenggara. Penelitian ini sejalan dengan penelitian Prapto, S. (2010) dalam penelitian ini dengan adanya pengendalian intern akuntansi dari setiap unit organisasi atau SKPD yang ada di lingkungan Pemerintah Kabupaten Minahasa Tenggara akan terwujudnya ketepatan dalam laporan keuangan. Dikarenakan dalam pengendalian intern akuntansi yang dijalankan dengan tepat pada setiap SKPD akan menjadikan kualitas laporan keuangan menjadi lebih baik, dan tentunya dengan kualitas laporan keuangan yang baik sehingga dalam penyajiannya dapat tepat waktu.

\section{KESIMPULAN DAN SARAN \\ Kesimpulan}

Berdasarkan hasil uji dan analisis data membuktikan ada pengaruh variabel yang diajukan sebagai alat ukur yaitu variabel kapasitas sumber daya manusia (X1), pemanfaatan teknologi informasi (X2), pengendalian intern akuntansi (X3), terhadap keandalan (Y1) dan ketepatan (Y2) dapat diambil kesimpulan sebagai berikut:

1. Hasil penelitian menunjukkan bahwa kapasitas sumber daya manusia mempengaruhi keandalan laporan keuangan di SKPD pada Pemerintah Kabupaten Minahasa Tenggara.

2. Hasil penelitian menunjukkan bahwa pemanfaatan teknologi informasi secara positif mempengaruhi keandalan laporan keuangan di SKPD pada Pemerintah Kabupaten Minahasa Tenggara.

3. Hasil penelitian menunjukkan bahwa pengendalian intern akuntansi secara positif mempengaruhi keandalan laporan keuangan di SKPD pada Pemerintah Kabupaten Minahasa Tenggara.

4. Hasil penelitian menunjukkan bahwa kapasitas sumber daya manusia secara positif mempengaruhi ketepatan laporan keuangan di SKPD pada Pemerintah Kabupaten Minahasa Tenggara.

5. Hasil penelitian menunjukkan bahwa pemanfaatan teknologi informasi secara positif mempengaruhi ketepatan laporan keuangan di SKPD pada Pemerintah Kabupaten Minahasa Tenggara.

6. Hasil penelitian menunjukkan bahwa pengendalian intern akuntansi secara positif mempengaruhi ketepatan laporan keuangan di SKPD pada Pemerintah Kabupaten Minahasa Tenggara.

\section{Saran}

Saran yang dapat diberikan berdasarkan hasil penelitian adalah:

1. Untuk kapasitas sumber daya manusia sebaiknya dalam penentuan posisi jabatan dalam pengelolaan keuangan di SKPD ditempati oleh pegawai yang berlatarbelakang pendidikan di bidang akuntansi, manambah pegawai yang berlatarbelakang pendidikan bidang akuntansi dalam pengelolaan keuangan SKPD pada Pemerintah Kabupaten Minahasa Tenggara. Pada pemanfaatan teknologi informasi disarankan untuk menambah jumlah fasilitas teknologi informasi seperti laptop dan personal computer untuk menunjang para pegawai dalam pengelolaan keuangan. Sedangkan pada pengendalian intern akuntansi disarankan agar para pegawai lebih memahami mengenai standar operasional prosedur (SOP) pada SKPD masing-masing terutama dalam pengelolaan keuangan. 
2. Menambah jumlah pelatihan-pelatihan dalam pengelolaan keuangan dan atau bekerja sama dengan lembaga/istansi terkait dalam pengelolaan keuangan seperti Badan Pegawasan Keuangan dan Pembangunan (BPKP) dan Program Magister Akuntansi Fakultas Ekonomi Universitas Sam Ratulangi Manado sebagai lembaga ilmiah.

3. Penelitian berikutnya diharapkan mempertimbangkan variabel-variabel lain yang belum dimasukkan dalam penelitian ini.

\section{DAFTAR PUSTAKA}

Adriani, Wiwik. 2010. Pengaruh Kapasitas Sumber Daya Manusia dan Pemanfaatan Teknologi Informasi Terhadap Keterandalan dan Ketepatwaktuan Laporan Keuangan Pemerintah Daerah. Jurnal Akuntansi dan Manajemen.Vol. 5.

Alimbudiono, Ria Sandra \& Fidelis Arastyo Andono. 2004. Kesiapan Sumber Daya Manusia Sub Bagian Akuntansi Pemerintah Daerah "XYZ" dan Kaitannya Dengan Pertanggungjawaban Keuangan Daerah Kepada Masyarakat: Renungan Bagi Akuntan Pendidik.Jurnal Akuntansi dan Keuangan Sektor Publik.Vol. 05 No. 02.Hal.18-30.

Darise, Nurlan. 2008. Akuntansi Keuangan Daerah (Akuntansi Sektor Publik). Jakarta : PT Indeks.

Dinata, Anton Mulhar. 2004. Tinjauan Atas Kesiapan SDM pada Instansi Pemerintah Kota Palembang dalam Penerapan Akuntansi Daerah Menuju Terciptanya Good Governance di Era Otonomi Daerah. Skripsi, Universitas Sriwijaya, Indralaya.

Ekasari, Winda. 2013. Faktor-faktor yang mempengaruhi keandalan pelaporan keuangan pemerintah daerah kabupaten Kampar. www.google.com.

Faristina, Rosalin. 2011. Faktor-faktor yang Mempengaruhi Keandalan dan Timeliness Pelaporan Keuangan Badan Layanan Umum, Studi pada BLU di Kota Semarang.Skripsi Universitas Diponegoro : Semarang.

Ghozali, Imam. 2005. Aplikasi Analisis Multivariate dengan Program SPSS. Edisi 3. Badan Penerbit Universitas Diponegoro, Semarang.

Gusrita, Ririn. 2013. Pengaruh pemanfaatan teknologi informasi dan sumber daya manusia terhadap keterandalan dan ketepatwaktuan pelaporan keuangan pemerintah daerah. www.google.com.

Indriasari, D. dan E. Narhatyo. 2008. Pengaruh kapasitas sumber daya manusia, pemanfaatan teknologi informasi dan pengendalian intern akuntansi terhadap nilai informasi pelaporan keuangan pemerintah daerah. Simposium Nasional Aakuntansi, XI. Pontianak.

Kuncoro, Mudrajat. 2003. Metode Riset Untuk Bisnis dan Ekonomi, Erlangga, Jakarta.

Luthans, Fred, 2005. Perilaku Organisasi, Edisi Sepuluh, Diterjemahkan oleh : Vivin Andhika Yuwono; Shekar Purwanti; Th.Arie Prabawati; dan Winong Rosari. Penerbit Andi, Yogyakarta.

Mahmudi. 2007. Manajemen Kinerja Sektor Publik.. Yogyakarta : UPP STIM YKPN.

Mardiasmo. 2006. Perwujudan Transparansi dan Akuntabilitas Publik Melalui Akuntansi Sektor Publik: Suatu SaranaGood Governance. Jurnal Akuntansi Pemerintah, Vol. 2 No. 1, Hal. 1-17.

Mustafa S, Sutrisno dan Rosidi. 2011. Analisis Faktor-faktor yang berpengaruh terhadap Keterandalan dan Ketepatwaktuan Pelaporan Keuangan pada SKPD Pemerintah Daerah Kota Kendari.

\section{Pemerintahan.}

, Peraturan Pemerintah Nomor 24 Tahun 2005 tentang Standar Akuntansi --, Peraturan Pemerintah Nomor 71 Tahun 2010 tentang Standar Akuntansi Pemerintahan. 
Peraturan Menteri Dalam Negeri Nomor 13 Tahun 2006 tentang Pedoman Pengelolaan Keuangan Daerah.

Sugiyono, 2008. Metode Penelitian Kunatitatif Kualitatif dan R\&D. Bandung Alfabeta.

Tuasikal, A. 2007. Pengaruh Pemahaman Sistem Akuntansi, Pengelolaan Keuangan Daerah Terhadap Kinerja Satuan Kerja Pemerintah Daerah (Studi pada Kabupaten Maluku Tengah di Provinsi Maluku). Jurnal Akuntansi Dan Keuangan Sektor Publik. Vol. 08, No. 01. Hal:1466-1468.

Turban, Rainer, Potter, "Introduction To Information Technology Pengantar Teknologi Informasi”, Edisi 3, Penerbit Salemba Infotek, 2006.

Wilkinson, W. Joseph, Michael J. Cerullo, Vasant Raval, and Bernard Wong-OnWing. 2000. Accounting Information Systems: Essential Concepts and Applications. Fourth Edition. John Wiley and Sons. Inc.

Winidyaningrum, C. dan Rahmawati. 2010. Pengaruh Sumber Daya Manusia dan Pemanfaatan Teknologi Informasi Terhadap Keterandalan dan Ketepatwaktuan Laporan Keuangan Pemerintah Daerah dengan Variabel Intervening Pengendalian Intern Akuntansi. Simposium Nasional Akuntansi, XIII, Purwokerto. 